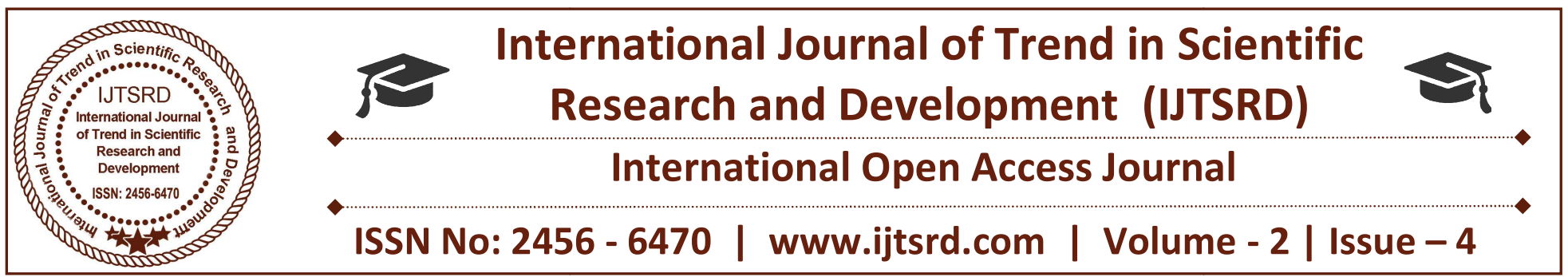

\title{
Women Health in Kerala Tribe - A Sociological Analysis of Muthuvan Community
}

\author{
Anusha V. M, Muhammed Atheeque. P. P \\ Department of Sociology, Bharathidasan University, Tiruchirappalli, Tamil Nadu, India
}

\begin{abstract}
Koodakkadukudi has 8 hamlets. Situated in Marayoor village. $9 \mathrm{~km}$ away from Marayoor town. 100 women are selected following systematic random sampling out of 478 families. In order to facilitate 3 objectives. Namely the social life of Muthuvan women and the educational conditions and the health related facts. It was found that Muthuvans are not aware of the harmful effects of unsafe drinking water. Their livelihood only depend on the natural source of water namely pond and river. They have no other option and are unaware of the unsafe drinking water. $90 \%$ of them make use of open area for execration and urination. This requires toilet construction in their area through government program among welfare activities from the village and self-help groups. Formation of self help groups is yet to be started.
\end{abstract}

Keywords: Women Health, Muthuvan Community and Kerala Tribe

\section{INTRODUCTION}

The Muthuvan people were very loyal subjects of the dynasty of Madurai, according to tribal legend. When the dynasty was deposed the surviving royal members migrated to Travancore, Central Kerala and established the famed Poonjar dynasty. On their way to Kerala the Muthuvans carried idols of Madurai Meenakshi on their backs. So the word Muthuvans is derived from the word "Muthuku" which means back in Tamil and Malayalam languages. The tribe which carried the idols on their backs later settled in the forest near Tamil Nadu and came to be known as Muthuvans.
Historically speaking, the Muthuvans are believed to have field from the Madurai district of Tamil Nadu, one of the state of India, situated at the southern end. The Muthuvans are very independent and reluctant to interact with the outside world. Muthuvan women are strictly prohibited from having contact with nonMuthuvans, especially non- Muthuvan men. There is a hamlet of Muthuvans at Machiuplavukudi near Adimali, Idukki district of Kerala. Most of their women are illiterate and strongly bonded with their customs. In Kerala Muthuvans tribal settlements are located at Marayoor, Vattavada, Suryanelli, Bison Valley, Mankulam, Adimali, Kuttampuzha and Adichithotti villages spread in Idukki, Ernakulam and Thrissur districts. Census of Kerala identified 9,903 Mudugar individuals from 2,185 families living in 88 settlements covering $67.6 \mathrm{~km}$ in the state. The area of study is Koodakkadukudi, situated in Marayoor Panchayathu of Devikulam Taluk. It has 8 hamlets namely Karppoorakudi, Kavakkudi, Kuthukalkudi, Periyakudi, Overthittukudi, Nellippettikudi, Vengapparakudi, Kammalamkudi. All the 8 hamlets together comprise 478 families, which are different from households. The distribution of families is given below.

\section{Purpose of Study}

The purpose of study was to assess the "interaction pattern of Muthuvan teenage girls" and the major issues affecting them. The issues involved in the research project included enquiry about their sociological life, religious activities, health and education, customs, heritage, tradition, marriage etc. 
International Journal of Trend in Scientific Research and Development (IJTSRD) ISSN: 2456-6470

\section{Objectives of the Study}

1. To understand the reasons for illiteracy and dropouts of tribal girls

2. To describe social life of Muthuvan Women

3. To bring out the health related facts of Muthuvan

\section{Population of the Study}

Population of the study is 1791Muthuvan Tribal people in which women constitute 886 . Sampling is Systematic random sampling (selected one women from five settlement). Sample size is 100 women are selected from 100 families. Unit of the study is individual people and research design of the study is descriptive research design.

\section{Data Collection Procedure}

The researcher approached the tribal development officer of Devikulam Taluk and Marayoor regional officer. After that took the permission of Marayoor DFO for entering the forest. The tribals were assured of the confidentiality of their responses and reminded that these responses would be used only for the purpose of research work. Afterwards they were satisfied and with much interest and co-operation they helped me in my collection of data. It was observed that the students were liked to answer all the questions. Most of them responded detail. They were found open minded and keen to answer. Some respondents raised doubts about this interview schedule and also about research process.

\section{Data Collection}

Data was collected from the respondents through personal interviews and also by using a structural questionnaire. Literature and survey of reference of journals gave more clarity for the researcher in determining the reluctant tools of data collection. The collection of data was done from by visiting Koodakkadukudi tribal settlement near Marayoor, Kerala.
Analysis and Interpretation

\section{Livelihood of Women Respondents}

\begin{tabular}{|l|l|l|}
\hline $\begin{array}{l}\text { Sources of } \\
\text { income }\end{array}$ & $\begin{array}{l}\text { Frequency } \\
\mathrm{N}=100\end{array}$ & Percentage \\
\hline Self - cultivation & 15 & $15 \%$ \\
\hline $\begin{array}{l}\text { Agriculture wage } \\
\text { labour }\end{array}$ & 20 & $20 \%$ \\
\hline Forest Product & 45 & $45 \%$ \\
\hline Handicrafts & 20 & $20 \%$ \\
\hline Total & 100 & $100 \%$ \\
\hline
\end{tabular}

Forest, forest resources play a significant role in the daily life of Muthuvans. Forest provides them food, medicine, fuel, wood and wide range of non - timber forest products, which are essential not only for meeting their requirements but also act as potential source of income for their livelihood and to keep up their for meeting their requirements. Women, including young and old pregnant are lactating from the major workfare in the agriculture activities of the Muthuvans. The Muthuvan women are hardworking; they work in the field during the day time. Men do support in agriculture work. Many young men are so engaged in loading work. They carry goods like rice and necessary items to the kudi and carry cardamom and other forest products outside the kudi.

From childhood, muthuvan women are trained to make bamboo products such as baskets, plates, vessels, chair, cots, hut, homes etc. They also make bamboo vessels and baskets which is used for agriculture and cooking purpose. Muthuvan men take honey from forest but they hardly use it for themselves; they sell it through VSS.Women, usually go once in a week to collect firewood and go more than once in a week, if there are any special needs. They need firewood for cooking.

\section{Agriculture}

More than $50 \%$ of Muthuvans in Koodakkadukudi possess their own land. The state government has given them the land for agricultural purposes but without a deed certificate. They only have possession certificate. The main agricultural crops grown by the Muthuvans include finger millet, paddy, tapioca and cardamom. Along with agriculture Muthuvans collect the wild tubers and honey from forest.

Muthuvans rear goats and chicken. But they neither use milk nor the egg. They believe goat milk is for 
goat kids and keep the egg for breeding. They usually go to work by 9 am in the morning and are in the field up to $3 \mathrm{pm}$. They often drink black tea without sugar. They eat twice in a day that is 9 am and $6.30 \mathrm{pm}$.

\section{Family wise Analysis of Pants Used by Muthuvans}

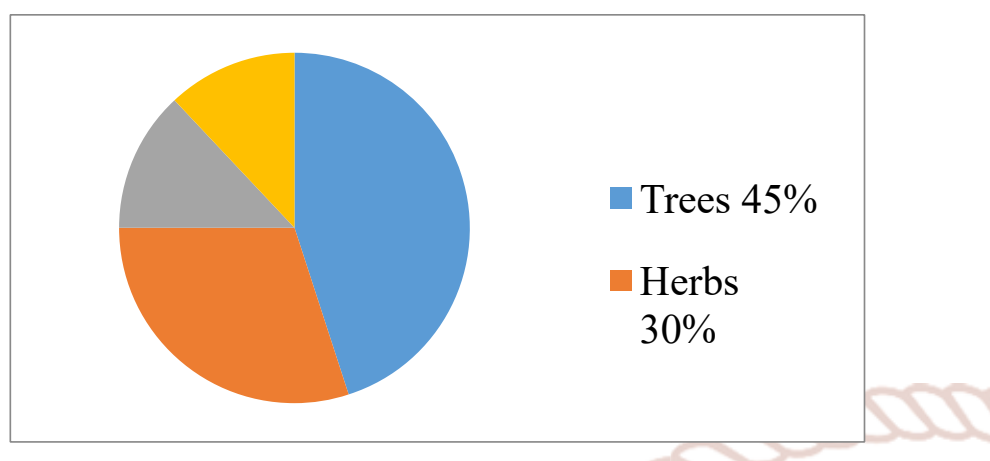

The knowledge of medicine of Muthuvans is indigenous based on their traditional experience. Modern science is yet to examine their knowledge .Plants and plant derivatives form major constituents in most of the medical preparations. They do not store medicines. The men opined that the efficiency of medicine will be lost as a result of long periods.

Now the deforestation resulted in the scarcity of various precious medicinal plants. They collect it from the natural habitat and they never cultivate them for their own use. There was a specialist medicine man known as Vaidhyan whose duty is to collect medicinal plants, preparation of medicines and treatment of the patients.

The main medicinal plants are :Maramanjal (Cosciniumfenestratum), Kaattumanjal (Christm), Eanth (Cycascircinalis L), Koovalam (Aeglemarmelos L Correa), Menthonni (Gloriosasuperba L), Vayambu (Acoruscalamus L), Garudakkody (Aristolochiatagala Cham), Anjili (Artocarpushirsutus Lam), Cherupunna (Calophyllumapetalum Wild), Perumkurumba (Chonemorphafragrans Alston), Karuva (CinnamomummacrocarpumHook.f), Kattukaruva (CinnamomumsulphuratumNees), (Vetiveriaianoides), Kacholam (Kaempferia galangal), Kattarvazha (Aloe vera), Pathimugham (Caesalpiniasappan), Thippali (Piper longum), Panikkoorkka (Coleus aromaticus), Aadalodakam (Adathodavasica), Brahmi (Baccopamonnieri), Krishna Thulasi (Oscimum sanctum)

Anthropologically Muthuvans are considered as a proto- Australoid in origin without a unique physic. They are health, tall, strong, fair with brownish curly hairs. According to some others they are considered to be migrated from Madurai region of Tamil Nadu during $13^{\text {th }}$ and $14^{\text {th }}$ century AD.

\section{Literacy Rate of Muthuvans}

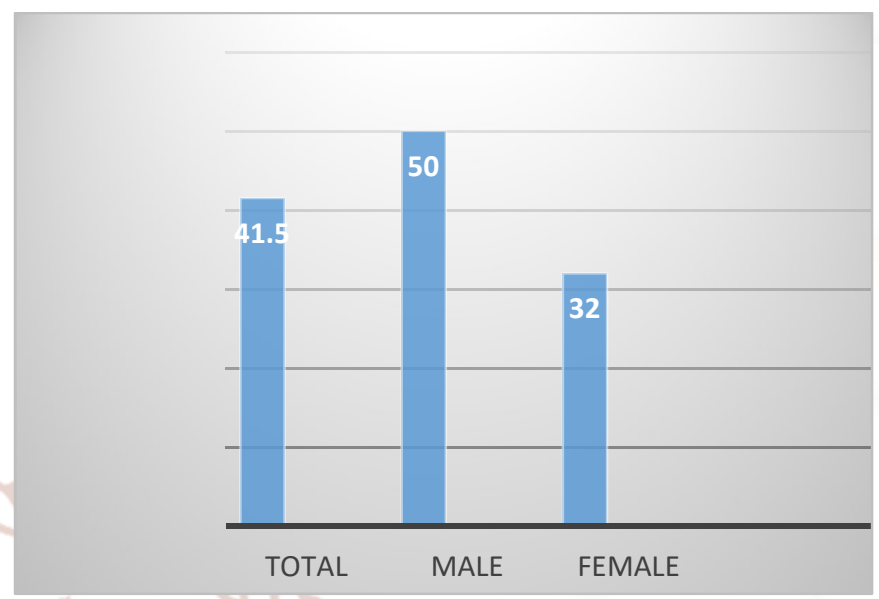

Though, Muthuvans represent $5.8 \%$ to the total tribal population of the state their literacy fall far below the general literacy rate. Literacy rate of Muthuvans is $41.5 \%$ which is even far below the national literacy rate of STs (census of India, 2001). It can also be seen the large difference existing between male and female literacy L rate of Muthuvans (50:30). Among the literates, about half of them have either attained primary level education or are literate without any formal education. The percentage of indicates low level of education among Muthuvans. Besides being one of the significant tribes they remain excluded from educational developmental process.

The Muthuvans are very poor. Many of the students discontinue schools at primary and middle school due to financial difficulties. But concerning Koodakkadukudi they have proper facilities for attaining education. They have two lower primary schools within the settlement. The state and central governments providing enough financial assistance in the form of scholarships, free boarding, lodging facilities, provision to text books and mid- day meals in primary schools, stipend hostel facilities, not many tribal children are not attached to education. The Muthuvans have not been earning much to educate themselves. Their cultural surroundings and poverty creates hindrances in the process of their education.

\section{Education of the Muthuvan Girl Children}

The reasons associated with not educating girl child are financial constraints, submissiveness and motherhood. In earlier days Muthuvans have a tradition to bring their girl children for marriage after reaching the menstruation periods or the age of 14 and 
above. But now the situations got change because of the new points of child protections and child marriage act. Because of that they are getting enough chances to attain education. But according to many points of view their lazy mind and their culture they don't like to getting educate. They views that without education they can live. The inner truth is mostly Muthuvan women are not ready to interact with others. So that they don't have any problem when they were illiterate.

Another major fact is, Muthuvans are strongly restricted their women for interactions of outside the settlement. And they believe that if higher education then they will get any affairs from outside of their community. Girls have no say on the topic of education. It is entirely their parent's decision. More than half of them wanted to send their daughters to schools but others thought it was futile. Where parents are enthusiastic about educating their daughters, they enroll their daughters in schools but rarely allow them to complete their education.

The Muthuvans are reluctant to send their girl children out of their settlement since they are very much concerned about the safety of their-daughters. Thus they discontinue their education at the primary level and turn to household chores and agricultural activities. But this ancient concept got a few changes. And now they have an idea to make them educate and highly percentage of parents are ready to bring their children to school. In Periyakudi Pugalenthi, is a final year degree girl's student. And her parents like to motivate her. Covering the entire kudi she was the only one girl who got higher education. Most commonly girls were managing household chores, helping in agricultural activities and taking care of younger children. Even if the schools were located in their hamlet itself due to these work burdens girl children were always withdrawn from the school. But by comparing other tribal settlement in Idukki, Koodakkadukudi have many good opportunities. It has two Anganavadies also.

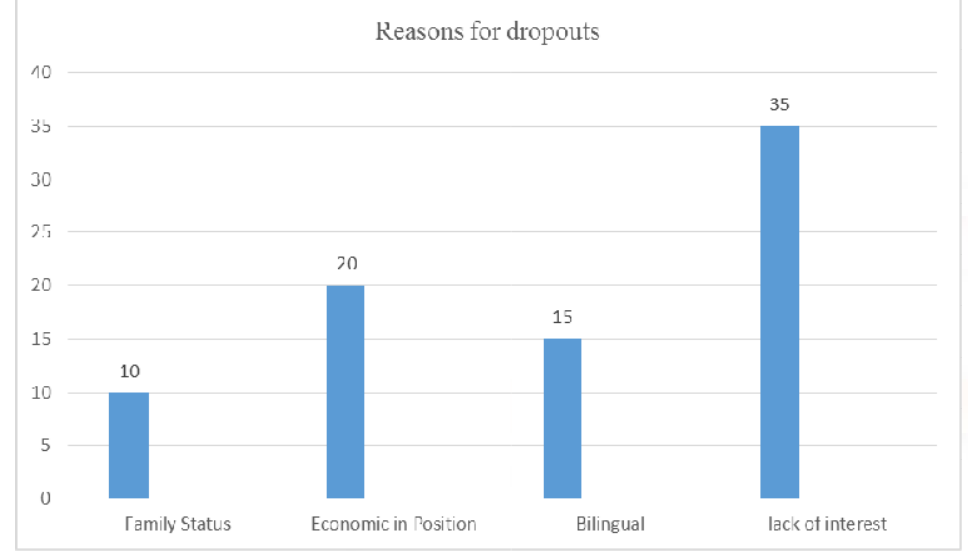

The reasons for drop-out are depending on family status, economic imposition, bi-lingual education, lack of interest etc. Among the Muthuvans it was found that the problem of drop-out is not an isolated phenomenon, but it may be attributed to so many other facts. Dropouts basically related to the socio economic culture and other constrains are the consciousness, involvement and educational level of parents, and also the neighboring groups and their influence. The main reason of dropout of girls remaining behind attitude of their parents. Commonly after menstruation parents are not ready to send them in schools.

\section{Number of Persons who completed $10^{\text {th }},+2$, Degree in Koodakkadukudi in 2015-16}

There are 8 hamlets in Koodakaaukodi. They are Karppoorakudi, Kavakkudi, Kuthukalkudi, Periyakudi, Overthittukudi, Vengapparakudi, Nellippethkudi, Kammalamkudi. Only two were completed SSLC in karpurakodi. In kavukodi 17 were completed SSLC and one completed plus Two. Kuthukalkodi and Overthettukudi one person completed SSLC. In periyakodi 10 Persons completed SSLC and only one completed plus two. Four persons passed degree. In Vengaparakudi 16 persons have SSLC and only one have Plus Two. In Nellipettikudi 8 persons have SSLC and one passed plus two and four persons were degree holders.in kammalamkudi the number of educates in SSLC is 6 and also 1 has plus two.

\section{Reasons for Dropouts}


International Journal of Trend in Scientific Research and Development (IJTSRD) ISSN: 2456-6470

\begin{tabular}{|l|l|l|l|l|l|l|}
\hline Panchayath & Tribal settlement & \multicolumn{4}{l|}{ Number of Educates } & \multirow{2}{*}{ Total } \\
\hline \multirow{4}{*}{ Marayoor } & Koodakkadukudi & SSLC & +2 & Degree & PG & \\
\hline & Karppoorakudi & 2 & - & - & - & 2 \\
\cline { 2 - 7 } & Kavakkudi & 17 & 1 & - & - & 18 \\
\cline { 2 - 8 } & Kuthukalkudi & 1 & - & - & - & 1 \\
\cline { 2 - 7 } & Periyakudi & 10 & 1 & 4 & - & 15 \\
\cline { 2 - 7 } & Overthittukudi & 1 & - & - & - & 1 \\
\cline { 2 - 7 } & Vengapparakudi & 16 & 1 & - & - & 17 \\
\cline { 2 - 7 } & Nellippethkudi & 8 & 1 & 4 & - & 13 \\
\cline { 2 - 7 } & Kammalamkudi & 6 & 1 & - & - & 7 \\
\hline Total & & 61 & 5 & 8 & & 74 \\
\hline
\end{tabular}

\section{Menstrual Hygiene of the Respondents}

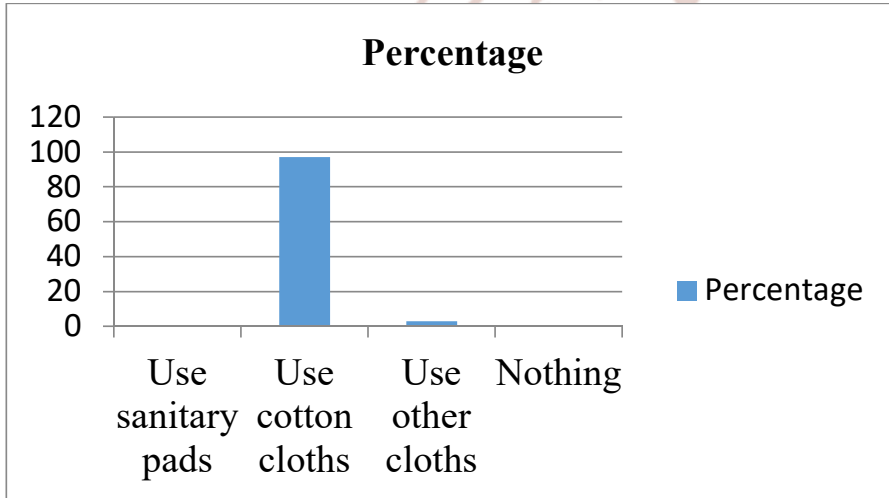

\section{Menarche}

Generally young women are poorly informed about their own sexuality and physical well-being. For many girls, the first menstruation is the frightening event about which they have not been informed. She is separated without explanation and kept out from other adults. At the end of the four or five days she is given a ritual bath. And subsequently she is treated as a woman eligible for marriage, kept away from her precious playmates and confined the house. Low rates of educational attainment, limited sex education and inhabited attitudes towards attenuate this ignorance. A brief overview of his lack of awareness suggests that adolescent girls are generally ignorant of menstruation and related behavioral norms like pollution and not necessarily its links to sexual life. Taw of the women in the study fell that if they had known about menstruation prior to menarche, they would have been less afraid, where as one woman fell that prior knowledge would have made her anxiously await menarche. Lack of awareness on menstruation makes girls depressed anxious on their menstruation. The timing of menarche among different population is probably affected by a variety of environmental, genetic and socio- economic factors; but most analysis consider nutritional status to be the dominant determinant.

\section{Teenage Girls}

The teenage girls required to get $1 \mathrm{~kg}$ Sakkara, $1 \mathrm{~kg}$ ragi, $1 / 2 \mathrm{~kg}$ peanuts. In between each three months they can $1 / 2 \mathrm{~kg}$ wheat also. It makes them healthy and physically fit. These facilities are provided under Anganavadies, and from there they are giving them hygiene classes. Key events in the life of young women before motherhood.

\section{Bath habit of Menstrual Days}

\begin{tabular}{|l|l|l|l|}
\hline $\begin{array}{l}\text { S1. } \\
\text { No. }\end{array}$ & $\begin{array}{l}\text { Bath habit in } \\
\text { Menstruation } \\
\text { Days }\end{array}$ & $\begin{array}{l}\text { Frequency } \\
\mathrm{N}=100\end{array}$ & Percentage \\
\hline 1 & Yes & 99 & 99 \\
\hline 2 & No & 1 & 1 \\
\hline \multicolumn{2}{|c|}{ Total } & 100 & 100 \\
\hline
\end{tabular}

The table shows that $99 \%$ of the respondents were bathing during the menstruation days and only $1 \%$ of the respondents were not take bath these days. 


\section{Marriage}

\begin{tabular}{|l|l|l|l|}
\hline S1.No & $\begin{array}{l}\text { Age of } \\
\text { marriage }\end{array}$ & $\begin{array}{l}\text { Frequency } \\
\mathrm{N}=100\end{array}$ & Percentage \\
\hline 1 & $13-16$ & 0 & $0 \%$ \\
\hline 2 & $17-20$ & 20 & $20 \%$ \\
\hline 3 & $21-24$ & 25 & $25 \%$ \\
\hline 4 & $25-28$ & 55 & $55 \%$ \\
\hline Total & 100 & $100 \%$ \\
\hline
\end{tabular}

Commonly Muthuvans marriage place between cross cousins. Traditionally, the first girl child should go in marriage to the paternal sister's son. In olden concept was age of marriage is from 13. But now the social situation totally changed. Because of child marriage act and women protection rules the age of marriage is reached 18 and above. In the olden days the marriage was a one week celebration for the entire kudi. Concerning Koodakkadukudi they are celebrating one week celebrations.

The ceremony begins when the bride's friends hide the bride and the groom and his friends should find her out. Friends of the bride roam in the forest by singing Ashappattu. And it misguides the boys. The people on the kudi do not go for work on these days. Every member of the kudi enjoys the playful atmosphere. Finally, either they find the bride or the groom and his friends plead her friends to show the bride. It is then the bride and groom meet with each other and the marriage ceremony begins. However, this custom is not practiced in the recent times. Now, the groom comes to bride's kudi, stays there for about two or three days without appearing in public, takes the bride and goes to his kudi. In between the girl's father gives a dinner to all people in the kudi. The groom's father also arranges a dinner at his kudi after the groom and bride reach their kudi after marriage. The groom is supposed to bring pudava (bridal sari) for the bride.

Age at which Respondents Got Pregnant and Delivery Took Place

\begin{tabular}{|l|l|l|l|}
\hline $\begin{array}{l}\text { Sl. } \\
\text { No }\end{array}$ & $\begin{array}{l}\text { Pregnancy } \\
\text { and Delivery } \\
\text { Period }\end{array}$ & $\begin{array}{l}\text { Frequenc } \\
\text { y N=100 }\end{array}$ & Percentage \\
\hline & 13 to 16 & 0 & 0 \\
\hline & 17 to 20 & 15 & 15 \\
\hline & 21 to 24 & 32 & 32 \\
\hline & 25 to 28 & 53 & 53 \\
\hline \multicolumn{2}{|c|}{ Total } & 100 & 100 \\
\hline
\end{tabular}

The table shows that more than $50 \%$ of the respondents got pregnant and delivery took place at the age group of $25-28$, and $32 \%$ are at the age group of $21-24$ and negligible $(15 \%)$ of the respondents are at the age group of $17-20$.

\section{Respondents Who Consulted a Doctor during Pregnancy}

\begin{tabular}{|l|l|l|l|}
\hline $\begin{array}{l}\text { Sl. } \\
\text { No. }\end{array}$ & $\begin{array}{l}\text { Consulting a } \\
\text { Doctor at the } \\
\text { Time } \\
\text { Pregnancy }\end{array}$ & $\begin{array}{l}\text { Frequency } \\
\mathrm{N}=100\end{array}$ & Percentage \\
\hline 1 & Yes & 21 & 21 \\
\hline 2 & No & 79 & 79 \\
\hline & Total & 100 & 100 \\
\hline
\end{tabular}

The table indicates that majority $(79 \%)$ of the respondents are not consulting the doctor during pregnancy / and (21\%) of the respondents are consulting the doctor during pregnancy.

\section{Respondents on the Basis of Lost their Infants}

\begin{tabular}{|l|l|l|l|}
\hline $\begin{array}{l}\text { S1. } \\
\text { No. }\end{array}$ & $\begin{array}{l}\text { Respondents } \\
\text { on the basis } \\
\text { of lost their } \\
\text { Infants }\end{array}$ & $\begin{array}{l}\text { Frequency } \\
\mathrm{N}=100\end{array}$ & Percentage \\
\hline 1 & Yes & 36 & 36 \\
\hline 2 & No & 64 & 64 \\
\hline & Total & 100 & 100 \\
\hline
\end{tabular}

$64 \%$ of the respondents have not lost their children and $36 \%$ of the respondents have lost their infants because of the unviability of the road and transport facilities and health care facilities.

\section{Reason for the Death of Children}

Only 38 mothers reported the reason for the death of their children. The reasons are given below. 
International Journal of Trend in Scientific Research and Development (IJTSRD) ISSN: 2456-6470

\begin{tabular}{|c|c|c|c|}
\hline $\begin{array}{l}\text { Sl. } \\
\text { No }\end{array}$ & $\begin{array}{l}\text { Reason for } \\
\text { the death of } \\
\text { children }\end{array}$ & $\begin{array}{l}\text { Frequenc } \\
\text { y N=100 }\end{array}$ & Percentage \\
\hline 1 & Jaundice & 0 & 0 \\
\hline 2 & Tetanus & 0 & 0 \\
\hline 3 & $\begin{array}{l}\text { Fever, } \\
\text { Vomiting, } \\
\text { dysentery }\end{array}$ & 13 & 34.21 \\
\hline 4 & $\begin{array}{l}\text { Reason } \\
\text { unknown }\end{array}$ & 25 & 65.79 \\
\hline & Total & 38 & 100 \\
\hline
\end{tabular}

Respondents who had ever gone to Hospital

\begin{tabular}{|l|l|l|l|}
\hline S1.No. & $\begin{array}{l}\text { Gone to } \\
\text { Hospital }\end{array}$ & $\begin{array}{l}\text { Frequency } \\
\mathrm{N}=100\end{array}$ & Percentage \\
\hline 1 & Yes & 66 & 66 \\
\hline 2 & No & 34 & 34 \\
\hline \multicolumn{2}{|r|}{ Total } & 100 & 100 \\
\hline
\end{tabular}

The table indicates that $65.79 \%$ of the children are dying without knowing the reason for death and only $34.21 \%$ are dying because of fever, vomiting and dysentery.

\section{Community Health Center Study of Muthuvan New Born}

\begin{tabular}{|l|l|}
\hline Year & No. of New Born \\
\hline $2012-2013$ & 7 \\
\hline $2013-2014$ & 8 \\
\hline $2014-2015$ & 8 \\
\hline
\end{tabular}

A study by the government community health Centre (CHC) in Devikulam says that 2012-13 saw even Muthuvan newborns, which rose to eight births in 2013-14. In 2015, another eight babies were born as of end July this year. The study also says the number of infertile women too has now gone down to 32 . The CHC study the usage of the pill has now come down. Too many Muthuvan women mostly illiterate or semi - literate, had been using cheap pill continuously for many years, often up to 8 or more years. This was not to avoid hearing children but to escape a tribal custom that forced them into disabling isolation every time they menstruated. Continuously using the pill ensured they would not menstruate.

In Marayoor village there is one primary health center and a private hospital also. But they are $10 \mathrm{~km}$ away from the settlement. Because of lack of vehicles and road facilities, the respondents going had gone to hospitals by walk. And another reason is they have herbal medicines for fever, stomach diseases. They even claim having medicines for cancer. Therefore, people do not prefer to go. The above indicates that majority of the respondents $(66 \%)$ have gone to hospital sometimes and one third (34\%) of the respondents have never gone to hospital.

\section{Routine of Bath}

\begin{tabular}{|l|l|l|c|}
\hline $\begin{array}{c}\text { Sl. } \\
\text { No. }\end{array}$ & $\begin{array}{l}\text { Respondents } \\
\text { routine of } \\
\text { bath } \\
1\end{array}$ & $\begin{array}{c}\text { Frequency } \\
\mathrm{N}=100\end{array}$ & Percentage \\
\hline 264 & $\begin{array}{l}\text { Once in two } \\
\text { days }\end{array}$ & 13 & 84 \\
\hline 3 & $\begin{array}{l}\text { Once in a } \\
\text { week }\end{array}$ & 2 & 13 \\
\hline 4 & $\begin{array}{l}\text { Twice in a } \\
\text { week }\end{array}$ & 1 & 1 \\
\hline & Total & 100 & 100 \\
\hline
\end{tabular}

The table says that majority of the responders $(84 \%)$ are taking bath every day, negligible $(13 \%)$ of the respondents take bath once in two days, few $(2 \%)$ of the respondents are taking bath only once in a week and negligible $(1 \%)$ of the respondents have the habit of taking bath twice in a week. The study in also exploring the frequency of taking bath. They take bath from pond and river. 
International Journal of Trend in Scientific Research and Development (IJTSRD) ISSN: 2456-6470

\section{Habits of Using Soap}

\begin{tabular}{|l|c|c|c|}
\hline $\begin{array}{l}\text { S1. } \\
\text { No. }\end{array}$ & $\begin{array}{l}\text { Respondents routine of } \\
\text { bath }\end{array}$ & $\begin{array}{l}\text { Frequency } \\
\mathrm{N}=100\end{array}$ & Percentage \\
\hline 1 & Soap & 100 & 0 \\
\hline 2 & Leaves & 0 & 0 \\
\hline 3 & Others & 0 & 0 \\
\hline
\end{tabular}

The above table shows that $100 \%$ of the respondents were using soap for cleaning their body.

\section{Routine of Washing Clothes}

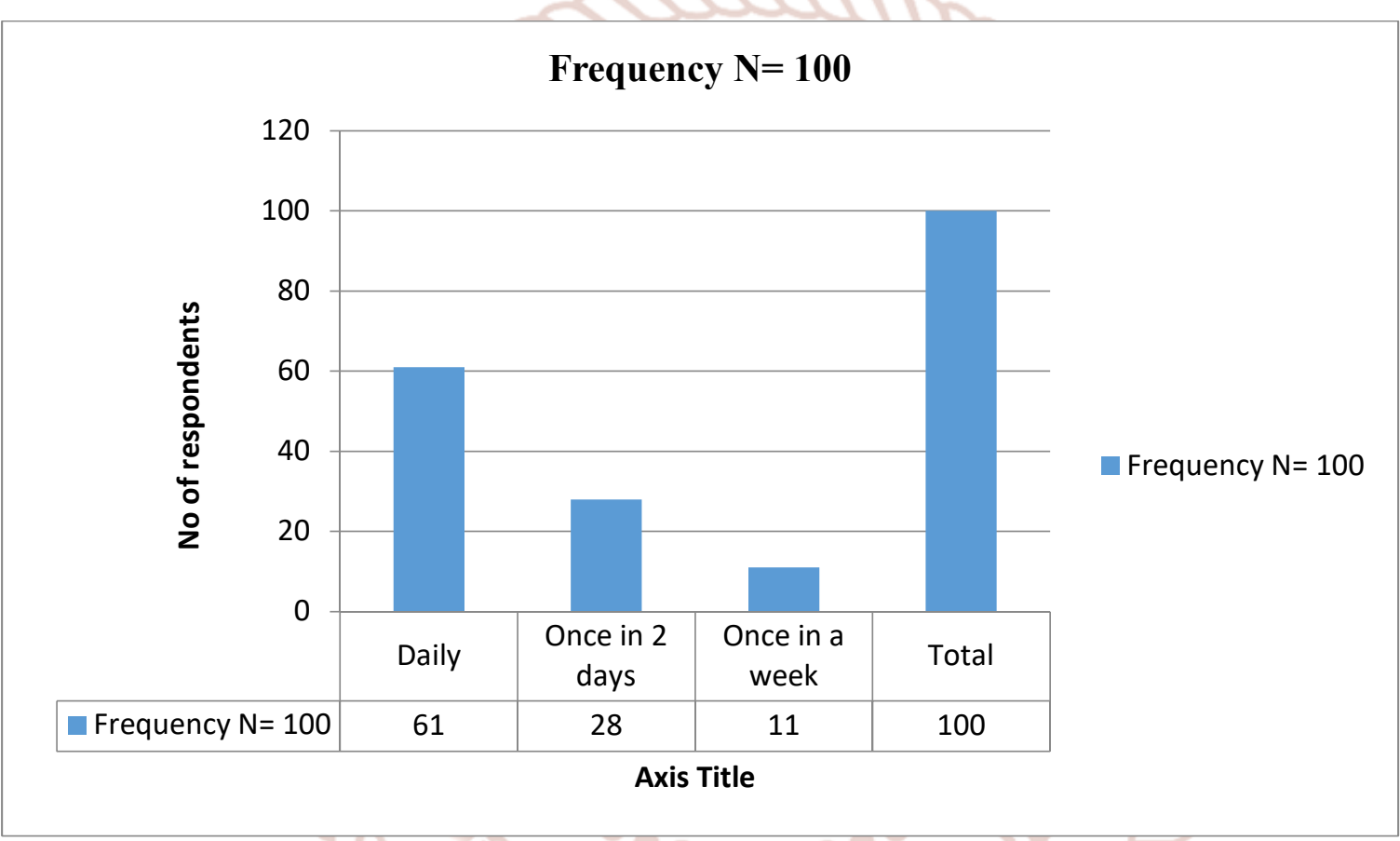

Only $61 \%$ of the total adult women population wash their daily used clothes. $28 \%$ of the total adult women wash their clothes only after using it for continuous The table shows that $100 \%$ of the respondents were cleaning their teeth daily. They brush their teeth by two days. But at $11 \%$ of the total were wash their They don't use commercial paste. clothes only after using it for a week.

\section{Dental Health}

\begin{tabular}{|l|l|l|l|}
\hline $\begin{array}{l}\text { Sl. } \\
\text { No } \\
\cdot\end{array}$ & $\begin{array}{l}\text { Cleaning } \\
\text { Your Teeth } \\
\text { daily? }\end{array}$ & $\begin{array}{l}\text { Frequency } \\
\mathrm{N}=100\end{array}$ & Percentage \\
\hline 1 & Yes & 100 & 100 \\
\hline 2 & No & 0 & 0 \\
\hline \multicolumn{2}{|c|}{ Total } & 100 & 100 \\
\hline
\end{tabular}

\section{Respondents with the habit of Chewing Pan}

\begin{tabular}{|l|l|l|l|}
\hline $\begin{array}{l}\text { Sl. } \\
\text { No. }\end{array}$ & $\begin{array}{l}\text { Do you have } \\
\text { the habit of } \\
\text { chewing pan? }\end{array}$ & $\begin{array}{l}\text { Frequency } \\
\mathrm{N}=100\end{array}$ & Percentage \\
\hline 1 & Yes & 45 & 45 \\
\hline 2 & No & 55 & 55 \\
\hline \multicolumn{2}{|c|}{ Total } & 100 & 100 \\
\hline
\end{tabular}


The table shows that more than half of the $(55 \%)$ respondents are not using pan and nearly half of the respondents $(45 \%)$ are using it. Muthuvan women have the habit of chewing pan made of betel leave mixed with betel nut throughout the day. It is selfmade.

\section{Main Health Issues of Muthuvan Women}

\begin{tabular}{|l|l|l|}
\hline Sl.No. & Name of Diseases & $\begin{array}{l}\text { No. of } \\
\text { Respondents }\end{array}$ \\
\hline 1 & Paralyze & 5 \\
\hline 2 & Respiratory problems & 20 \\
\hline 3 & Malnutrition & 35 \\
\hline 4 & Menstrual problems & 25 \\
\hline 5 & Others & 20 \\
\hline
\end{tabular}

The main health issues of muthuvan women are due to malnutrition. Another big issue related to menstruation. Both this issues they are unaware of many governmental projects to overcome their pathetic situation. 5\% of respondents affected paralyze issues and $20 \%$ have respiratory problems. Uncontrolled use of intoxicating drinks, use of tobacco products, and chewing pans may be reasons for these kinds of diseases. Muthuvan women see new shirring of life. Women of Muthuvan tribes in the forest of Koodakkadukudi in Idukki are beginning to escape the unintended scourge of modern contraceptive pill, which the government has introduced to them in the mid-1990s. The Pill, Mala Da heavily subscribed oral contraceptive pushed countrywide through the government's social marketing blitz for birth control - largely aiming the rural, less than affluent sections - had rendered infertile a big chunk of women of this tribe.

\section{Dispose of the Excreta of the Children}

\begin{tabular}{|l|l|l|l|}
\hline $\begin{array}{l}\text { Sl. } \\
\text { No. }\end{array}$ & $\begin{array}{l}\text { Dispose of } \\
\text { the excreta } \\
\text { of the } \\
\text { children }\end{array}$ & $\begin{array}{l}\text { Frequency } \\
\mathrm{N}=100\end{array}$ & Percentage \\
\hline 1 & $\begin{array}{l}\text { Dig and bury } \\
\text { it }\end{array}$ & 5 & 5 \\
\hline 2 & Throw away & 95 & 95 \\
\hline 3 & Others & 0 & 0 \\
\hline & Total & 100 & 100 \\
\hline
\end{tabular}

The table shows that $95 \%$ of the respondents throw away their children's excreta and $5 \%$ of the respondents are dig and bury it.

\section{Awareness of Diseases}

\begin{tabular}{|l|l|l|l|}
\hline $\begin{array}{l}\text { S1. } \\
\text { No. }\end{array}$ & $\begin{array}{l}\text { Do you know } \\
\text { about the Diseases } \\
\text { Spread by flies } \\
\text { and mosquitoes? }\end{array}$ & $\begin{array}{l}\text { Frequency } \\
\text { N=100 }\end{array}$ & Percentage \\
\hline 1 & Yes & 43 & 43 \\
\hline 2 & No & 57 & 57 \\
\hline & Total & 100 & 100 \\
\hline
\end{tabular}

The table shows that more than half $(57 \%)$ of the respondents don't know about epidemic diseases and only $43 \%$ of the respondents know about it. Muthuvan women normally have the diseases of vomiting, menstruation problems, paralyzing, respiratory problems and malnutrition.

\section{Toilet Facilities of the Respondents}

\begin{tabular}{|l|l|l|l|}
\hline $\begin{array}{l}\text { S1. No. } \\
\text { and }\end{array}$ & Toilet facilities & $\begin{array}{l}\text { Frequency } \\
\mathrm{N}=100\end{array}$ & Percentage \\
\hline 1 & Deep Pit & 0 & 0 \\
\hline 2 & Small Pits & 0 & 0 \\
\hline 3 & Closet & 10 & 10 \\
\hline 4 & Open area & 90 & 90 \\
\hline Total & & 100 & 100 \\
\hline
\end{tabular}

The table shows that majority of the respondents $(90 \%)$ are using open area for toilet purpose and only a negligible percentage $(10 \%)$ of the respondents are using closet. The open toilets are one main reason for their unsafe and unhealthy water sources and water pollution. They use open toilets primarily because they are uneducated to their personal and social hygiene. This is presented in the following diagram.

\section{Conclusion}

The discussion attempts to trace the deep rooted elements of 'tradition' in the life of muthuvan and is set against the background of modern world views, life styles and practices. The dynamics in the practices are also traced here. An important thrust of this study 
is to approach and analyze the concepts and realities from the perspective of women, especially in the area of sexual and reproductive health practices. The life of girl in Muthuvan community is different from that of girl living outside. Among muthuvan culture clan, lineages very strong particularly for marriage and they mostly follow it and strictly prohibited endogamy. Based on their schooling, some of them stop education and some continue going to school after upper primary level Indebtedness is a particularly great problem for many family from time to time social obligations made to be met, for instance marriage, puberty, birth, death, or any other occasions that call for a festival or celebration, 'also, if there is an occasion, when self - furtherance is being threatened. There is a threat of starvation. It is necessary for them to get a loan or help.

There houses are unhygienic. But being, they are bound to leave in the same house. Unhygienic conditions affects the health of the tribes. The houses of tribes lack windows and holes for the entrance of air and light in the house. This affects skin and health of the tribes. Due to the lack of proper communication and transportation facilities, government doctors, nurses, health servants posted at health centers do not want to leave in tribal area. They also prepare medicines from the medicinal plants and bones, teeth, tail, skin, horns, oil of wild animals and birds. They also perform magic to care their illness. They have to depend on ground water or well for drinking water. Still majority of tribal have to use the water of ponds for cooking and drinking purposes. They wash clothes on the banks of the same pond. Animals are also washed in the pond .Open toilets are also near the pond. Such activities make the water contaminated. It affects their health.

Due to lack of good transport and infrastructure facilities many pregnant ladies can't reach near $b$ hospitals in time and so they give birth to their children on the way itself. It endangers the very life of the mother and the child at the same time. Within the short time of 20 to 30 years the tribal had lost much including in some case of their independence and usually their land to money lenders who established themselves in the tribal area. The new settlers encroached upon the tribal land and managed to clean or take it in several methods of exploitation and trickery.

\section{Findings and Suggestions}

This descriptive study was undertaken to assess the entire life of Muthuvan women with special references to the tribal settlement of Koodakkadukudi at Marayoor in Idukki district. The data were collected from 100 women belonging to 8 hamlets in the basis of interview schedule.

1. Though they are geographically far away city life. They keep their own culture and life which may be better than our so called and city life.

2. They should not have proper and good infrastructure facilities including transportation and health.

3. Awareness programmes on their own keeping their own life is recommended. At the same time, they should be trained in modern education. Our primary challenge is a healthy margin of their own culture and life with modern education and gives on human life and science.

\section{References}

1) Johncy Manithottamans MS Francis (2017 Jan) 'Indian journal of traditional knowledge' Vol.6(1)

2) P. K. Muraleedharan (2014): "Edamalakkudy: Oorum Porulum" (Malayalam article)

3) Mohammed Awais \& NaheenHaider Zaidi (2014): "Tribal and Rural Development, -Various facts and innovative strategies", (Article) Regal Publications, Delhi.

4) Religion as a barrier in women empowerment; THE HINDU Nov.18- 2013-

5) N Viswanathan Nair (2013) 'Revival of tribal medicine'

6) Abha Anoop (2013 May 23) 'Many takes for tribal remedies, ancient cure, THE HINDU

7) Fr. J. Kurias (2012): "Highranginte Kudiyetta Charithram" (History Malayalam)

8) S. N. Chaudhary (2012): “Tribal Education: Implications for Development" (Essay) Concept Publishing Company, Delhi.

9) A. Naganna \& Ch. Uma Mohan (2011): “Tribal Developmental Programmers and Social 
Transformations" (Article) Discovery

Publications, Delhi.

10) Sangeetha Unnithan (2011): 'Edamalakkudi still routed in tradition' (The Hindu)

11) N. K. Das (2009): “Tribes Culture - Adaptation \&amp; Belief System - Conceptual and Methodological Perspectives" (Article), Serials Publications, Delhi.

12) N Viswanathan Nair (2008): 'Tribal health and medicines in Kerala'

13) JW Prakash (3 July 2008): 'Indian journal of traditional knowledge'

14) A.V. Yadappanavar (2003): "Tribal Educations in India" (Article) Discovery Publications, Delhi.

15) Padmaja Sen (2003): "Changing Tribal Life: A Socio - philosophical perspective”. (Essay) Concept publishing company, Delhi.

16) E. A. Karunakaran Nair (1987): "Idukkiyude Katha” (Malayalam article), National book, Kottayam.

17) Edgar Thurston and K Rangachari (1909): 'Caste and Tribes of Southern India.Vol.7 